\title{
Perbandingan Karakteristik Mutu Biobriket Kulit Durian Dan Jenis Briket Arang Berdasarkan Persentase Volatile Matter
}

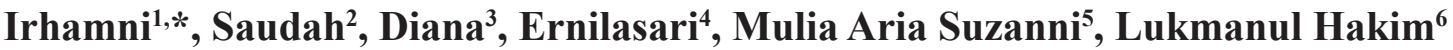 \\ ${ }^{1}$ Fakultas Teknik Universitas Serambi Mekkah, Banda Aceh \\ ${ }^{5}$ Akademi Farmasi Makanan dan Minuman Banda Aceh \\ ${ }^{6}$ Fakultas Pertanian Universitas Serambi Mekkah, Banda Aceh \\ J1. T.Imum Lueng Bata, Batoh, Banda Aceh \\ * Koresponden email: irhamni@serambimekkah.ac.id
}

Diterima: 6 Juli 2018

Disetujui: 28 Agustus 2018

\begin{abstract}
Bioarang is charcoal (one type of fuel) made from various kinds of biological materials, for example wood, twigs, leaves, grass that can be carbonized. biobriquette is an alternative energy substitute for fuel produced from organic materials or agricultural waste (biomass) that is underutilized, especially durian shell waste. This study aims to look at the comparison of the quality characteristics of the durian shell biobriquette with the type of charcoal based on the percentage of volatile matter. The making of this biobriquette uses 1: 2 pati janeng from the biobriquette weight, the biobriquette particle size is 80 mesh, the cylindrical biobriquette form. The results showed that the biobriquette produced had met the fuel quality standards for households. Level biobriquette of durian shell volatile matter is obtained $6 \%$, and for the type of volatile matter charcoal is $5 \%$. Based on the quality standard for volatile matter is a maximum of $15 \%$. Volatile matter test for biobriquette durian shell obtained can be used as an environmentally friendly fuel.
\end{abstract}

Keywords: durian shell, biobriquette, volatile matter, pati janeng

Abstrak. Bioarang merupakan arang (salah satu jenis bahan bakar) yang dibuat dari aneka macam bahan hayati, misalnya kayu, ranting, daun-daun, rumput yang dapat dikarbonisasi. Biobriket merupakan energi alternatif pengganti bahan bakar yang dihasilkan dari bahan-bahan organik atau limbah pertanian (biomassa) yang kurang termanfaatkan terutama limbah kulit durian. Penelitian ini bertujuan untuk melihat perbandingan karakteristik mutu biobriket kuit durian dengan jenis arang berdasarkan persentase volatile matter. Pembuatan biobriket ini menggunakan bahan perekat pati janeng sebanyak 1:2 dari berat biobriket, ukuran partikel biobriket adalah 80 mesh, bentuk biobriket selinder. Hasil penelitian menunjukkan bahwa biobriket yang dihasilkan telah memenuhi standar mutu bahan bakar untuk rumah tangga. Kadar Biobriket kulit durian volatile matter yang di dapat sebesar 6\%, dan untuk jenis arang volatile matternya sebesar 5\%. Berdasarkan standar mutu untuk volatile matter sebesar max 15\%. uji volatile matter untuk biobriket kulit durian yang diperoleh dapat digunakan sebagai bahan bakar ramah lingkungan.

Kata kunci : kulit durian, biobriket, volatile matter, pati janeng

\section{Pendahuluan}

Semakin bertambahnya populasi penduduk menyebabkan kebutuhan akan bahan bakar semakin meningkat sehingga dibutuhkan sumber alternatif yang lain. Salah satu energi terbarukan yang perlu mendapatkan perhatian untuk dikembangkan adalah biomassa. Pertumbuhan jumlah penduduk yang terus meningkat menyebabkan permintaan energi semakin meningkat. Dampak ini menyebabkan timbulnya kekhawatiran akan terjadinya kelangkaan 


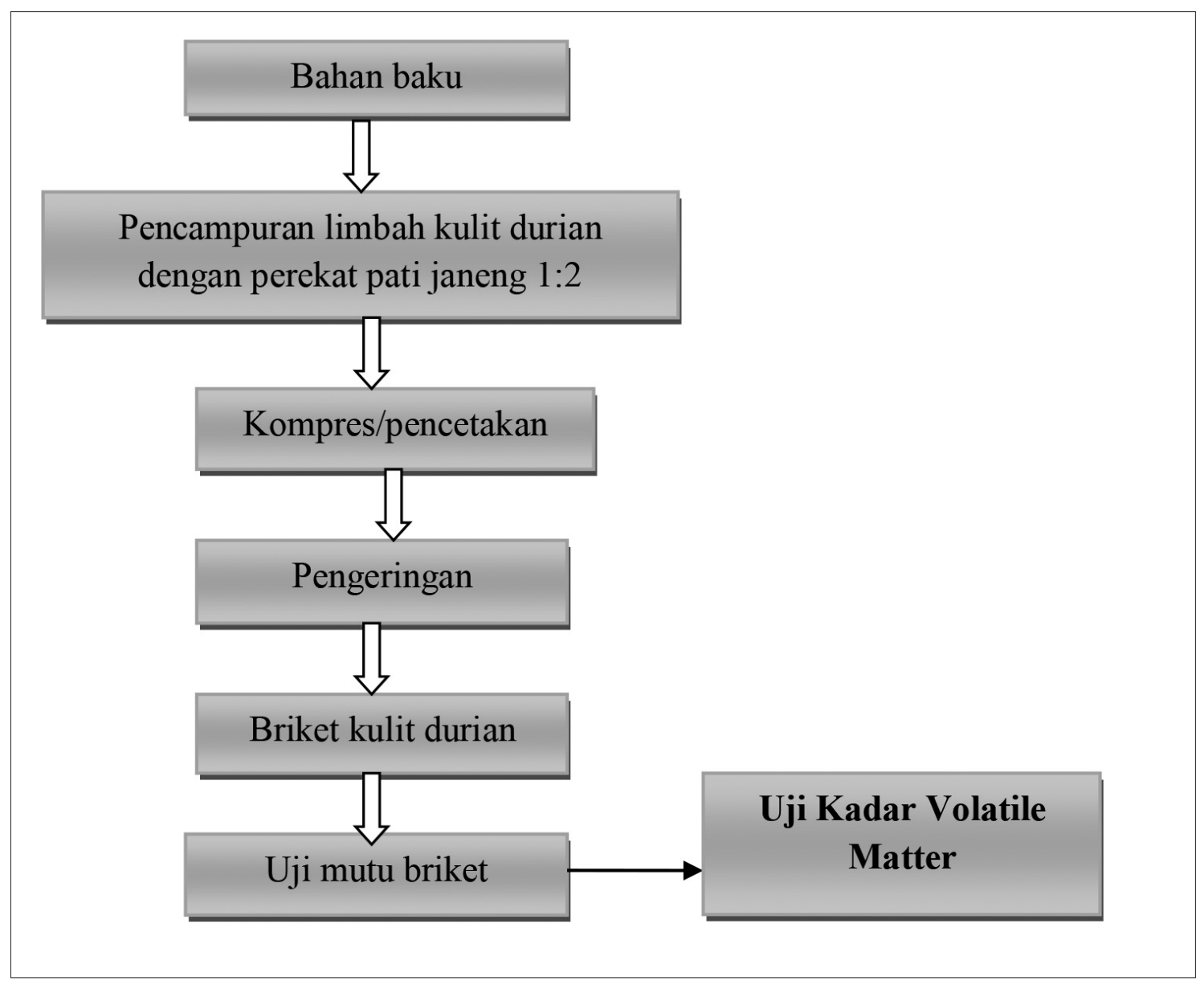

Gambar 1. Diagram alir pembuatan briket kulit durian

bahan bakar di masa yang akan datang. Dengan demikian perlu diupayakan sumber energi alternatif lain yang berasal dari bahan baku yang bersifat kontinyu dan dapat diperbaharui seperti energi biomassa (Hendra, 2007).

Limbah kulit durian dapat dianggap sebagai bahan baku utama untuk fermentasi lanjt dalam pembuatan bioetanol, yang memiliki aplikasi yang lebih luas sebagai bahan bakar terbarukan, baik dalam industri dan masyarakat pedesaan di negara negara berkembang (Irhamni, dkk, 2017).

Penambahan enzim melalui proses sakarifikasi dan liquifikasi untuk menghasilkan bioetanol. Bioetanol murni diperoleh melalui proses destilasi menggunakan Rotary Evaporator, kemurnoan bioetanol dianalisis menggunakan alat GC-MS (Irhamni, dkk, 2017).

Biomassa adalah suatu limbah padat yang bisa dimanfaatkan lagi sebagai sumber bahan bakar (Syafi'i, 2003). Biomassa yang dijadikan sebagai bahan bakar alternatif harus ramah lingkungan, mudah diperoleh, ekonomis digunakan oleh masyarkat (Maryono et al., 2013). Upaya dalam rangka penyediaan energy alternative adalah dengan memanfaatkan limbah organic sebagai bahan baku. Berdasarkan Statistik Energi Indonesia disebutkan bahwa potensi energi biomassa di Indonesia cukup besar, mencapai 434.008 GWh (Arief, 2015).

Limbah kulit durian meupakan biomassa yang memiliki potensi besar sebagai bahan baku alternativ untuk energi terbarukan. Kandungan utama yang dapat dimanfaatkan adalah karbohidrat. Kandungan karbohidrat pada kulit durian cukup tinggi. Serat kulit durian merupakan limbah dari buah durian, sekitar $60-75 \%$ adalah serat kulit durian dari buah durian. kulit durian terdiri dari oflignin (15,45\%), hemiselulosa $(13,09 \%)$ dan selulosa $(60,45 \%)$ (N. Nur Aimi et al., 2014). Penggunaan enzim alpha-amilasi dan gluko-amilase dapat meningkatkan produksi bioetanol pada limbah kulit durian sebagai bahan 


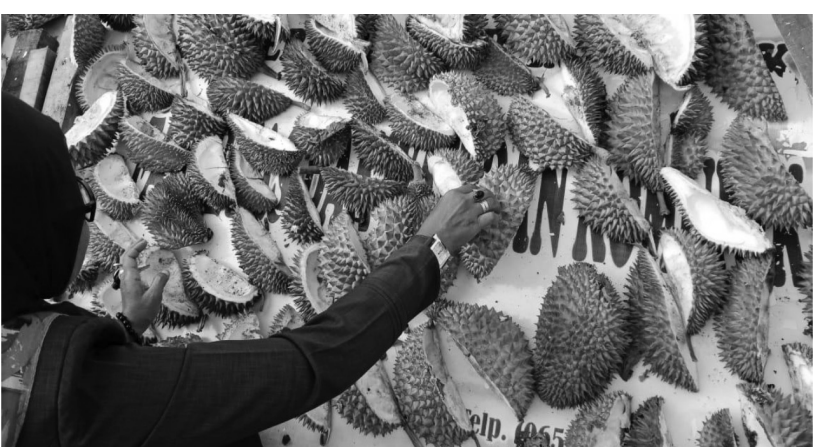

Gambar 2. Penjemuran kulit durian menjadi arang

bakar alternatif yang ramah lingkungan (Irhamni, et al, 2017). Seiring datangnya musim durian di kota Banda Aceh dan Aceh Besar, meningkatnya limbah kulit durian yang menjadi perhatian bagi Pemko kebersihan Lingkungan Hidup.

Hasil kulit durian yang telah dikumpulkan dan diseleksi, dicuci dengan aquadesh agar kulit durian bebas dari zat pengotor, kulit durian yang sudah bersih dipotong kecil - kecil dan digerai untuk diangin- anginkan, kemudian kulit durian dikeringkan ke dalam oven pada suhu $600^{\circ} \mathrm{C}$ selama tiga hari (Irhamni, dkk, 2017).

Oleh karena itu, dilakukan pemanfaatan limbah kulit durian menjadi biobriket dengan penambahan pati janeng sebagai energi alternatif yang ramah lingkungan.

\section{Metodologi Penelitian}

a. Alat dan Bahan

Peralatan yang di gunakan adalah ayakan mesh, gelas ukur, pengaduk, hot plate, baskom, cetakan biobriket, Oven, Bomb Calorimeter, Furnace, desikator, Strenght Test. Bahan pembuatan briket adalah limbah kulit durian, pati janeng sebagai perekat dan air panas. Pemilihan pati janeng sebagai perekat karena mengandung sekitar 20\% amilosa dan 80\% amilopektin, berpotensi menjadi perekat yang baik,

\section{b. Prosedur penelitian}

Prosedur penelitian meliputi, persiapan bahan baku, persiapan bahan perekat, dan pembuatan briket.

1. Persiapan bahan baku

Pada proses ini, bahan baku dipotong menjadi ukuran kecil, kemduian dikeringkan di bawah sinar matahari samapi kadar air 12\%, dan selanjutnya dikarbonisasikan pada suhu $400^{\circ} \mathrm{C}$.

2. Persiapan perekat pati janeng

Umbi janeng dicuci bersih untuk menghilangkan racun sianida, dipotong dadu dan di blender dengan penambahan aquadest $100 \mathrm{ml}$. Bubur janeng kemudian dipanaskan hingga mengental.

3. Pembuatan briket

Arang kulit durian yang sudah disaring dicampurkan dengan perekat pati janeng dengan ditambahkan sedikit air sambil di aduk rata hingga menggumpal. Adonan arang dimasukkan kedalam cetakan kemudian dikering dalam oven pada suhu $60^{\circ} \mathrm{C}$. Biobriket yang sudah kering kemudian dilakukan analisa mutu biobriket yaitu, persentase kadar volatile matter nya.

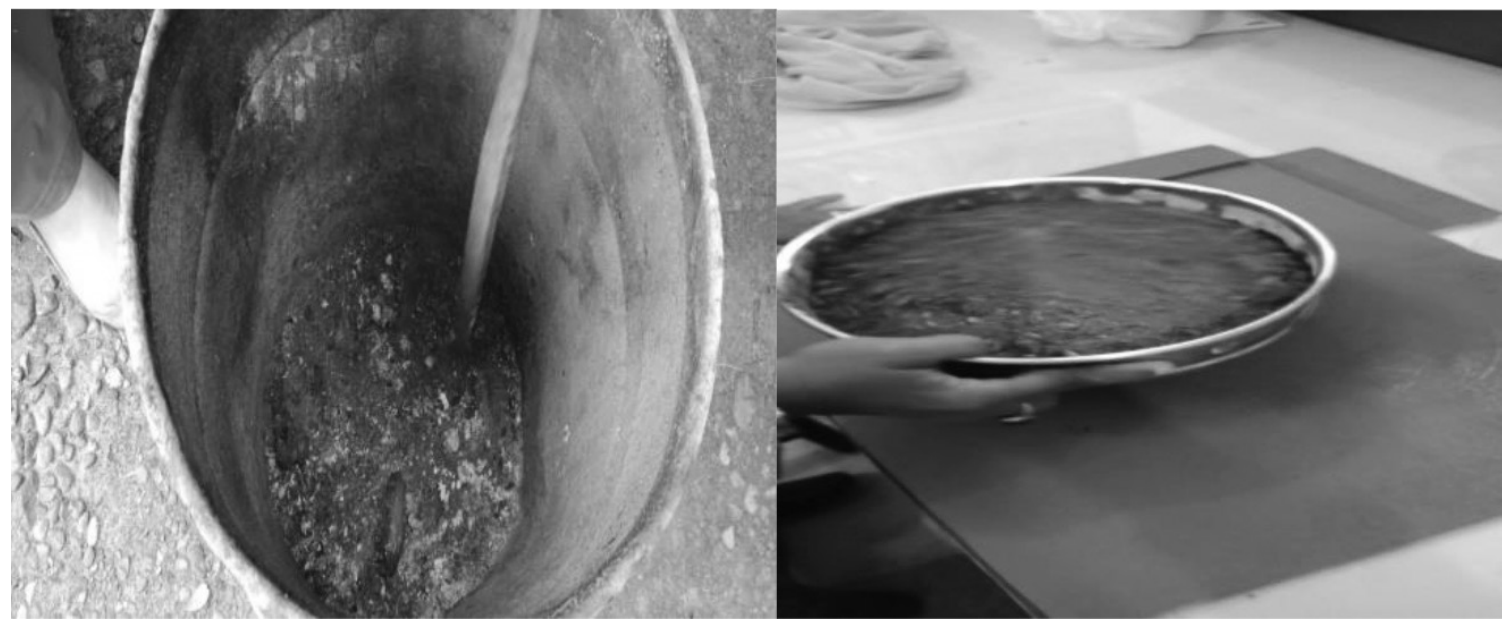

Gambar 3. Pembakaran kulit durian menjadi arang 
Tabel 1. Hasil data karakteristik mutu biobriket kulit durian dengan jenis briket arang

\begin{tabular}{lcc}
\hline \multicolumn{1}{c}{ Jenis Briket } & \multicolumn{2}{c}{ Hasil Analisis } \\
\cline { 2 - 3 } & $\begin{array}{c}\text { Volatile Matter } \\
(\%)\end{array}$ & $\begin{array}{c}\text { Standar Mutu } \\
\text { SNI 01-6235-2000 } \\
\end{array}$ \\
& 5 & $(\%)$ \\
\hline Al (Arang) & 6 & Max 15 \\
\hline B1(BioBriket) & & Max 15 \\
\hline
\end{tabular}

\section{Hasil Dan Pembahasan}

\section{a. Pembuatan Biobriket Kulit Durian}

Kulit durian merupakan limbah organik yang berpotensi dan berpeluang untuk dijadikan bahan bakar. Kulit durian digunakan sebagai bahan dasar dalam pembuatan briket, karena tingginya kandungan selulosa, hemiselulosa dan lignin (N. Nur Aimi et al., 2014). Pada musim durian, volume kulit durian melimpah dan tidak dimanfaatkan, yang mengakibatkan terjadinya pencemaran limbah. Sehingga, untuk meningkatkan penggunaannya, kulit durian dibuat menjadi briket sebagai bahan bakar alternatif.

Limbah kulit durian yang akan dijadikan briket dibersihkan terlabih dahulu dan dikeringkan dibawah sinar matahari untuk selanjutnya dikarbonisasikan. Proses karbonisasi dilakukan dengan menggunakan kiln drum dengan suplai udara terbatas. Arang yang dihasilkan dari karbonisasi $100 \mathrm{~kg}$ limbah kulit durian yaitu sebesar $25 \mathrm{~kg}$ atau $25 \%$.

Arang yang terbentuk dari proses karbonisasi digiling dengan menggunakan mesin penggiling untuk memperkecil ukuran partikel arang. Serbuk arang diayak dengan ayakan 80 mesh. Perekat yang digunakan dalam penelitian ini merupakan tepung janeng. Umbi janeng merupakan bahan alami yang mudah diperoleh dengan biaya murah. Pati dalam umbi janeng sekitar 56-78\% dari berat kering (Narlis, et la. 2016). Campuran arang dengan perekat janeng dicetak dengan mengunakan cetakan silinder. Pengeringan dilakukan dalam oven pada suhu $60^{\circ} \mathrm{C}$ selama 3 $\mathrm{x} 24$ jam.

Pembuatan briket arang dari limbah kulit durian dengan menggunakan perekat pati janeng $2: 1$. Hasil pengujian mutu briket arang kulit durian dapat di lihat pada Tabel 1. Data karakteristik mutu Jenis Briket Arang dengan Biobriket kulit durian dan dibandingkan dengan standar kualitas briket arang Indonesia.

\section{b. Pembuatan Perekat Pati Janeng}

Kulit durian merupakan limbah organik yang berpotensi dan berpeluang untuk dijadikan

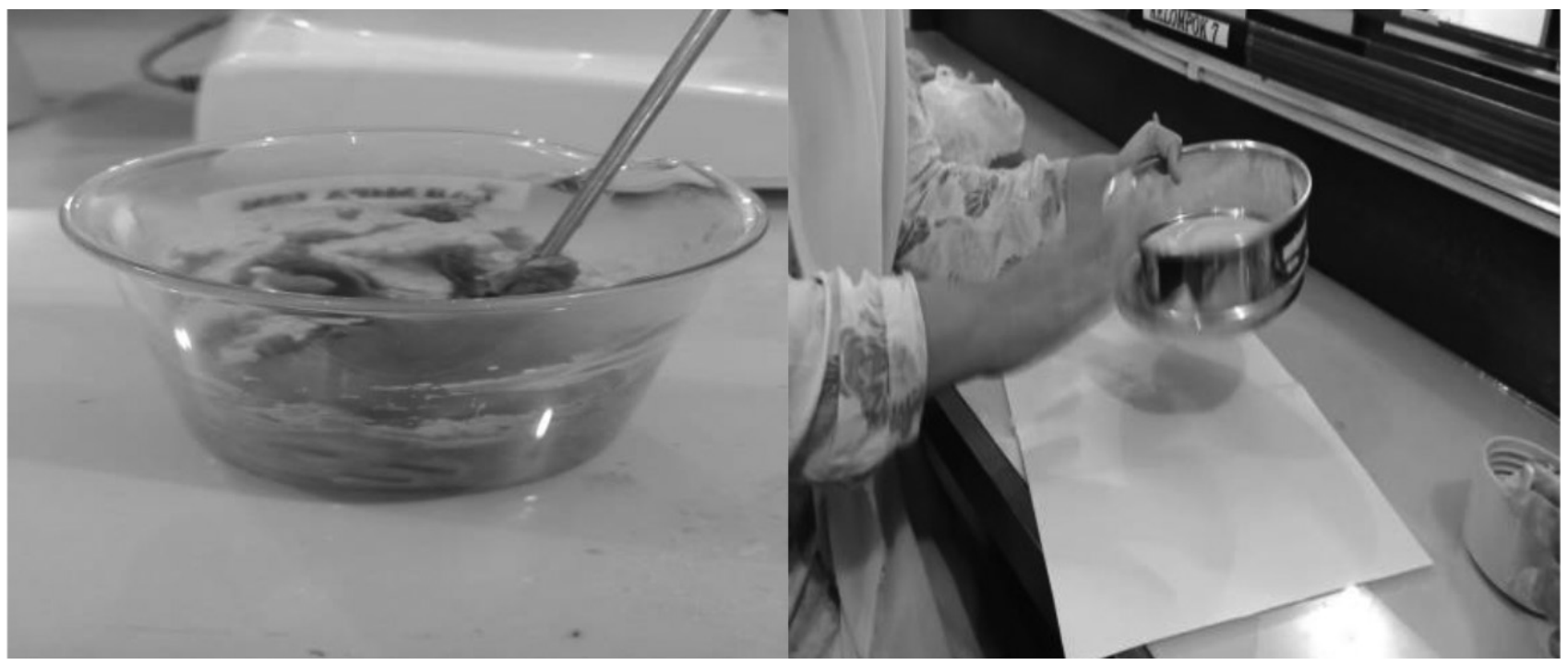

Gambar 4. Pembuatan perekat pati janeng 


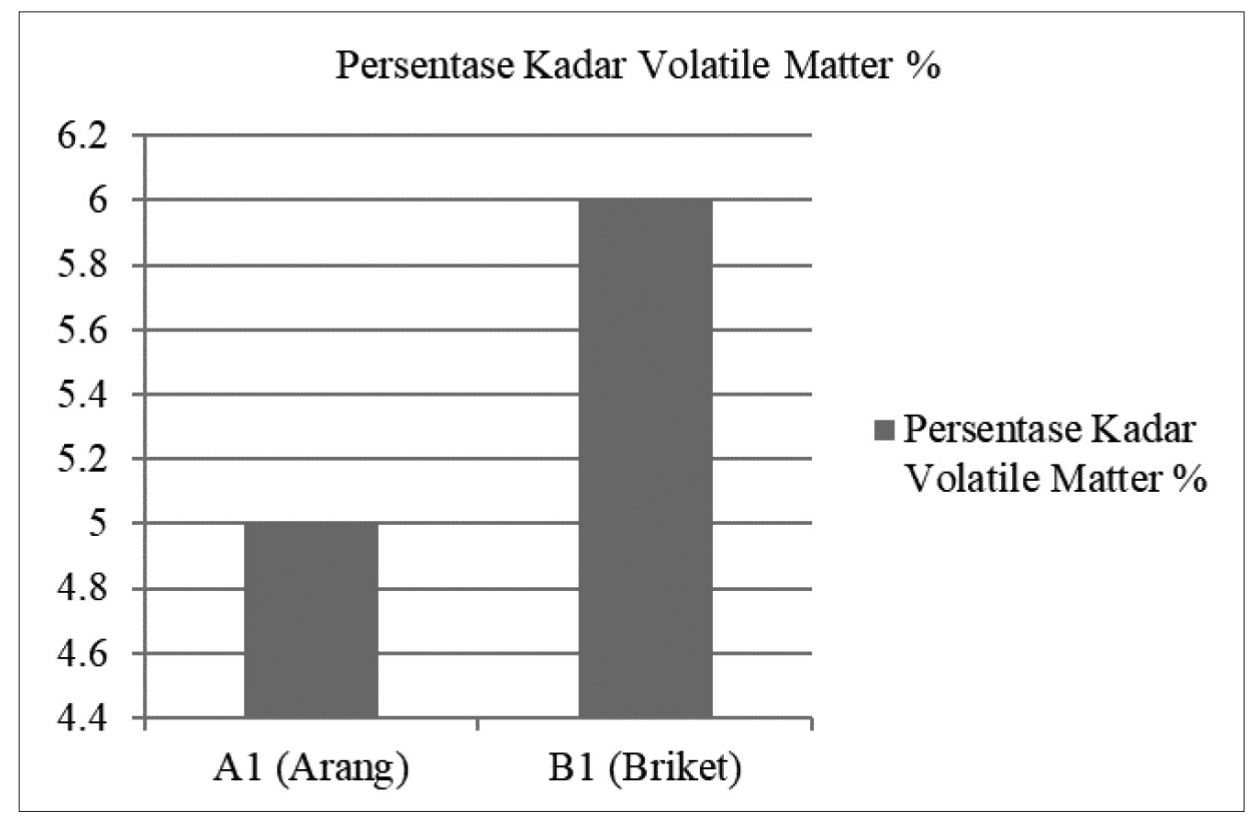

Gambar 5. Hasil Persentase Kadar Volatile Matter Jenis Briket Arang dengan BioBriket Kulit Durian

bahan bakar. Kulit durian digunakan sebagai bahan dasar dalam pembuatan briket, karena tingginya kandungan selulosa, hemiselulosa dan lignin (N. Nur Aimi et al., 2014). Pada musim durian, volume kulit durian melimpah dan tidak dimanfaatkan, yang mengakibatkan terjadinya pencemaran limbah. Sehingga, untuk meningkatkan penggunaannya, kulit durian dibuat menjadi briket sebagai bahan bakar alternatif.

Limbah kulit durian yang akan dijadikan briket dibersihkan terlabih dahulu dan dikeringkan dibawah sinar matahari untuk selanjutnya dikarbonisasikan. Proses karbonisasi dilakukan dengan menggunakan kiln drum dengan suplai udara terbatas. Arang yang dihasilkan dari karbonisasi $100 \mathrm{~kg}$ limbah kulit durian yaitu sebesar $25 \mathrm{~kg}$ atau $25 \%$. Arang yang terbentuk dari proses karbonisasi digiling dengan menggunakan mesin penggiling untuk memperkecil ukuran partikel arang. Serbuk arang diayak dengan ayakan 80 mesh.

Perekat yang digunakan dalam penelitian ini merupakan tepung janeng. Umbi janeng merupakan bahan alami yang mudah diperoleh dengan biaya murah. Pati dalam umbi janeng sekitar 56-78\% dari berat kering (Narlis, et la.
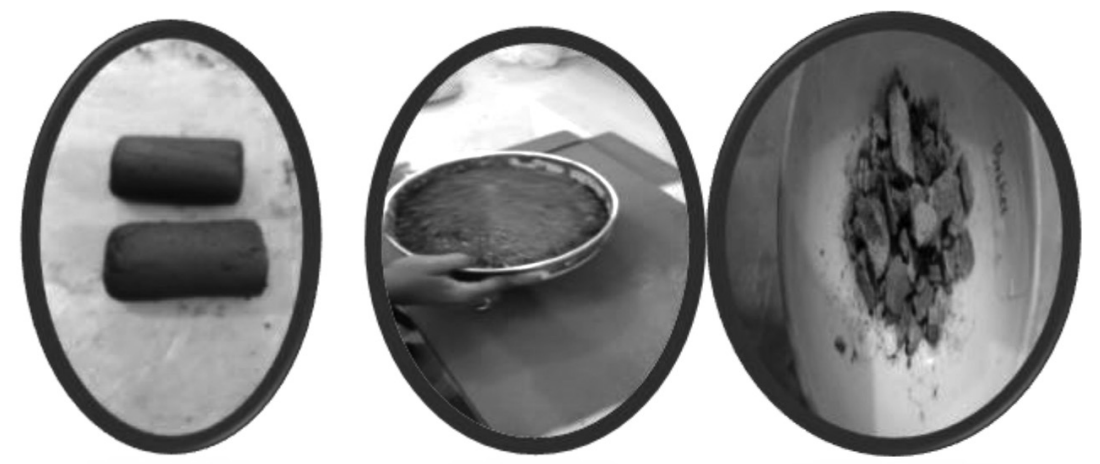

Gambar 6. A,B,C Biobriket kulit durian dengan perekat Pati Janeng

2016). Campuran arang dengan perekat janeng dicetak dengan mengunakan cetakan silinder. Pengeringan dilakukan dalam oven pada suhu $60^{\circ} \mathrm{C}$ selama $3 \times 24$ jam. c. Perbandingan Persentase Kadar Volatile Matter Jenis Arang Dan Jenis Biobriket Kadar volatile matter biobriket arang kulit 
durian yang dihasilkan sebesar 6\% seperti pada table 1 dan gambar 5. Sedangkan jenis briket arang sebesar 5\%. Kadar volatile matter biobriket arang kulit durian lebih tinggi dibandingkan kadar volatile matter briket arang, dan persyaratan kadar volatile matter briket arang kayu dalam SNI 01-6235-2000, yaitu maksimum 15\%. Djoko P dan Sofyan (2014), mengemukakan Kadar zat terbang yang tertinggi $(39,03 \%)$ dihasilkan dari tempurung kelapa sawit pada suhu $400^{\circ} \mathrm{C}$ dengan waktu pengarangan 4 jam dan kadar zat terbang yang terendah $(18,31 \%)$ diperoleh pada tempurung kelapa sawit yang diarangkan pada suhu $600^{\circ} \mathrm{C}$ dengan waktu 2 jam.

Pada Gambar. 6, A. B. C hasil biobriket kulit durian dengan menggunakan perekat pati janeng sampai menjadi abu dari hasilkan uji nyala selama penyalaan berwarna keabuan dan sangat halus, menandakan kualitas kadar abu sesuai dengan Standar Baku Mutu SNI. Dari awal penyalaan hingga menjadi abu, biobriket dari limbah kulit durian dengan menggunakan perekat pati janeng tidak menghasilkan asap pembakaran. Sehingga biobriket ini layak dijadikan sebagai bahan bakar alternatif terbarukan yang ramah lingkungan.

\section{Kesimpulan}

Mutu briket arang dengan perekat pati janeng ukuran 80 mesh diperoleh kadar volatile matter sebesar 6\%, memenuhi baku mutu SNI. Sehingga biobriket ini layak dijadikan sebagai bahan bakar alternatif terbarukan yang ramah lingkungan.

\section{Saran}

Disarankan untuk melakukan penelitian lebih lanjut terhadap daya tahan briket, dan karakteristik mutu lainnya

\section{Ucapan Terima Kasih}

Peneliti mengucapkan terimakasih banyak kepada Kementerian Pendidikan dan Kebudayaan Republik Indonesia atas bantuan dana hibah Penelitian Terapan Unggulan Perguruan Tinggi (PTUPT) dan Universitas Serambi Mekkah serta
LPPM USM yang memfasilitasi penelitian ini.

\section{Daftar Pustaka}

Arief, T. 2015. Panduan Penilaian Potensi Biomassa sebagai Sumber Energi Alternatif di Indonesia. Penabulu Alliance. Jakarta.

Djoko. P dan Sofyan. 2014. Pengaruh Suhu dan

Waktu Pengarangan Terhadap Kualitas Briket Arang dari Limbah Tempurung Kelapa Sawit. Jurnal Litbang Industri, 4(1): 29-38.

Hendra, D. 2007. Pembuatan Briket Arang Dari Campuran Kayu, Bambu, Sabut Kelapa, Dan Tempurung Kelapa Sebagai Sumber Energy Altenatif. Journal of Forest Product Research, 25(3): 242-255.

Irhamni., Diana., Saudah., M. A Suzanni., Ernilasari., 2017. Produksi Bioetanol dari Limbah Kulit Durian. Proseding SemdiUnaya, 1: 281-288.

Irhamni., Diana., Saudah. 2017. Bioetanol Limbah Kulit Durian Dengan Metode Sakarifikasi dan Liquifikasi. Jurnal Serambi Engineering, Vol 2(3): 114-117.

Irhamni., Diana., Saudah., M.A Suzanni., V Viena., 2017. Liquifikasi, Sakarifikasi dan Fermentasi Limbah Kulit Durian Sebagai Bahan Baku Produksi Bioetanol Menggunakan Saccharomyces cerevisiae. Proseding Seminar nasional II USM, I: 73-77.

Maryono., Sudding., dan Rahmawati. 2013. Pembuatan dan Analisis Mutu Briket Arang Tempurung Kelapa Ditinjau dari Kadar Kanji. Jurnal Chemica, 14(1): 74-83.

N. Nur Aimi, H. Anuar, M.R. Manshor, W.B. Wan Nazrib, S.M. Sapuan, (2014). Optimizing The Parameters In Durian Skin Fiber Reinforcedpolypropylene Composites By Response Surface Methodology. Journal Elsevier Industrial Crops and Products, 54: 291-295.

Narlis. J., Rahmi, dan H. Helwati. 2016. Effect Of Plasticizers On Mechanical Properties of Edible Film From Janeng Strarch-Chitosan. Jurnal Natural, 16(2): 45-49. 